NBER WORKING PAPER SERIES

\title{
UNDER PRESSURE? THE EFFECT OF PEERS ON OUTCOMES OF YOUNG ADULTS
}

\author{
Sandra E. Black \\ Paul J. Devereux \\ Kjell G. Salvanes \\ Working Paper 16004 \\ http://www.nber.org/papers/w16004
}

\author{
NATIONAL BUREAU OF ECONOMIC RESEARCH \\ 1050 Massachusetts Avenue \\ Cambridge, MA 02138
}

May 2010

Devereux thanks the Irish Research Council for the Humanities and Social Sciences (IRCHSS) for financial support. Black and Devereux gratefully acknowledge financial support from the National Science Foundation. Salvanes thanks the Research Council of Norway for financial support. We would like to thank Eve Caroli, Per-Anders Edin, Kanika Kapur, Eric Maurin, Steve Trejo, and seminar participants at Paris School of Economics, NYU, Carnegie Mellon/University of Pittsburgh, University of Oregon, University of Houston/Rice University, Texas A\&M, the University of Texas, Austin, and UCLA Anderson School of Business for helpful comments, We are indebted to Stig Jakobsen who was instrumental in obtaining data access to the IQ data from the Norwegian Armed Forces. This research was completed while Black was on leave at the Department of Economics at the University of Texas at Austin. The views expressed herein are those of the authors and do not necessarily reflect the views of the National Bureau of Economic Research.

NBER working papers are circulated for discussion and comment purposes. They have not been peerreviewed or been subject to the review by the NBER Board of Directors that accompanies official NBER publications.

(C) 2010 by Sandra E. Black, Paul J. Devereux, and Kjell G. Salvanes. All rights reserved. Short sections of text, not to exceed two paragraphs, may be quoted without explicit permission provided that full credit, including $\left({ }^{\circ}\right.$ notice, is given to the source. 
Under Pressure? The Effect of Peers on Outcomes of Young Adults

Sandra E. Black, Paul J. Devereux, and Kjell G. Salvanes

NBER Working Paper No. 16004

May 2010

JEL No. I20,J10

\begin{abstract}
$\underline{\text { ABSTRACT }}$
A variety of public campaigns, including the "Just Say No" campaign of the 1980s and 1990s that encouraged teenagers to "Just Say No to Drugs", are based on the premise that teenagers are very susceptible to peer influences. Despite this, very little is known about the effect of school peers on the long-run outcomes of teenagers. This is primarily due to two factors: the absence of information on peers merged with long-run outcomes of individuals and, equally important, the difficulty of separately identifying the role of peers. This paper uses data on the population of Norway and idiosyncratic variation in cohort composition within schools to examine the role of peer composition in 9th grade on longer-run outcomes such as IQ scores at age 18, teenage childbearing, post-compulsory schooling educational track, adult labor market status, and earnings. We find that outcomes are influenced by the proportion of females in the grade, and these effects differ for men and women. Other peer variables (average age, average mother's education) have little impact on the outcomes of teenagers.
\end{abstract}

Sandra E. Black

Department of Economics

University of Texas

Austin, TX 78712

and IZA

and also NBER

sblack@austin.utexas.edu

Paul J. Devereux

School of Economics

and Geary Institute

University College Dublin

Belfield, Dublin 4

Ireland

and IZA and CEPR

devereux@ucd.ie
Kjell G. Salvanes

Department of Economics

Norwegian School of Economics \& Business

Hellev. 30, N-5035 Bergen, NORWAY

IZA and CEP

kjell.salvanes@nhh.no 


\section{Introduction}

The "Just Say No" campaign of the 1980s and 1990s encouraged children to resist peer pressure and "say No" to drugs. A key underlying assumption of the campaign, based on research by Dr. Richard Evans, is that teenagers are susceptible to the influences of their peers. Despite this perceived wisdom, there is little large-scale empirical evidence on the long run effect of peers in middle school and high school. This is primarily due to two factors: the absence of information on peers merged with long-run outcomes of individuals and, equally important, the difficulty of separately identifying the role of peers. Using data on the population of Norway and idiosyncratic variation in cohort composition within schools, this paper examines the role of peer composition in $9^{\text {th }}$ grade on longer-run outcomes such as IQ scores, teenage childbearing, educational choices, adult labor market status, and earnings. Taken together, the findings provide a broad understanding of the socio-economic effects of peer composition.

We extend the existing literature on peer effects along two dimensions. First, we focus on the role of lower secondary school peers (when children are aged 14 to 16) instead of earlier schooling; teenagers are often perceived as being particularly susceptible to peer influence. Second, we are able to look at long-run outcomes and are not limited to test scores while in school. It is possible that short-term effects of peers on school grades wear off over time and hence are not so important in determining completed educational attainment and later earnings. ${ }^{1}$

\footnotetext{
${ }^{1}$ This type of effect has been observed with respect to the effects of school starting age. For example, Elder and Lubotsky (2009) find that it has large initial impacts on school grades but the effects get smaller with age.
} 
A key difficulty in the literature is the statistical identification of peer effects. ${ }^{2}$ In this paper, we use plausibly random peer group variation to identify the role of peers on long run outcomes. Starting with Hoxby (2000), researchers have exploited across-grade variation in peers within schools that arises because of random demographic differences across cohorts. For example, by chance, $3^{\text {rd }}$ grade may be $55 \%$ male in 2000 in a certain school, but only $45 \%$ male the following year. ${ }^{3}$ One concern with this strategy, however, is that parents may time the entry age of their child to avoid "bad" cohorts; we deal with this issue by instrumenting the actual peer characteristics of children with what the peer characteristics would have been if all children started school on time and progressed one grade each year. Because, in Norway, the compliance rate with school starting age regulations is high and grade retention is extremely rare, the first stage relationship is very strong.

We study how a child's outcomes are influenced by the gender composition of classmates, their socio-economic characteristics (as proxied by their mother's educational attainment), and the average age of classmates. The latter variable is influenced by much prior research suggesting that school starting age influences the long-run outcomes of children; in this paper, we continue this area of investigation by examining whether there are spillover effects on classmates. For example, based on earlier work, there is good

\footnotetext{
${ }^{2}$ Manski (2000) notes that typically behaviors and outcomes are similar among members of the same peer group and categorizes the possible reasons into 3 groups: (1) Endogenous peer effects occur when individual outcomes directly influence outcomes of peers (2) Exogenous or contextual peer effects occur when predetermined characteristics of individuals affect outcomes of peers and (3) correlated effects refer to non-peer effects reasons for correlated outcomes within peer groups such as endogenous peer group selection and correlated unobservables of peers. For empirical researchers trying to find evidence of peer effects, the identification problem amounts to separating (3) out from (1) and (2). See Manski (2000) and Moffitt (2001). In this paper, we use the term "peer effects" to refer to the combination of endogenous and contextual peer effects.

${ }^{3}$ A disadvantage of this approach is that exogenous variation in peer groups is at the grade-level rather than at the classroom-level, as the across-classroom distribution of children within grades is likely to be nonrandom.
} 
reason to suspect that having older peers may make it more likely that a teenage girl engages early in sexual activity and hence is more likely to have a teen birth. ${ }^{4}$

Our main finding is that students are influenced by the proportion of females in the grade. Interestingly, there are opposite effects for men and women, in that women benefit from having a higher proportion of female peers while men are disadvantaged by female peers. There is very little evidence that the other peer variables we study (average age, average mother's education) have any impact on the outcomes of teenagers.

The paper unfolds as follows. In section 2 , we discuss the relevant literature. The empirical methodology and institutional context are described in sections 3 and 4 respectively. Section 5 outlines the data we use. The main results are in section 6 . Section 7 concludes and summarizes the findings.

\section{Literature Review}

The publication of the Coleman report (1966) highlighted the importance of peers to the performance of students, arguing that peers are more important than schools as determinants of student outcomes. Since that time, researchers have tried a variety of estimation strategies to isolate the causal effect of peers on student performance. ${ }^{5}$

Most recently, the research in the area has taken on three basic strategies. The closest to ideal is the randomization of peer assignment, enabling the researcher to eliminate all concerns about selection. As with other experimental work, however, this is often limited in its generalizability. The best known experimental work on peers has focused on college roommate assignment (see work by Sacerdote (2001), Zimmerman

\footnotetext{
${ }^{4}$ See Black, Devereux, and Salvanes (2008).

${ }^{5}$ Sacerdote (2008) and Epple and Romano (forthcoming) provide comprehensive reviews of the literature.
} 
(2003), Carrell, Fullerton, and West (2009)), or has focused on elementary schools in developing countries (Duflo, Dupas, and Kremer (2008)). ${ }^{6}$ None of this experimental work has looked at the role of early teenage peers in a developed nation context.

The second identification strategy uses individual fixed effects; variation comes from changes in peer groups over time, primarily due to school-switchers and children who are held back. These changes in peer groups are then related to changes in the outcomes of the student, most generally as reflected in test scores. ${ }^{7}$ Hanushek, Kain, Markman, and Rivkin (2003) use student and school-by-grade fixed effects to estimate the effect of elementary school peers on test score gains. There are two sources for variation in peers: mobility into or out of the school and, less importantly, changes in student circumstances (income or achievement, for example). They find a positive effect of peer achievement on test score gains that is relatively constant across quartiles of the school achievement distribution. A key limitation of this strategy, however, is that it relies on movers for variation in peers, and the decision to move may be endogenous to school characteristics. ${ }^{8}$

A third estimation strategy is to use idiosyncratic variation across school cohorts to isolate the role of peers. Most closely related to our work is that of Hoxby (2000),

\footnotetext{
${ }^{6}$ Duflo, Dupas and Kremer (2008) randomize peer groups in Kenya. A key advantage of their paper is, because of the experimental design, they are able to compare the effects of peers in the presence of student tracking to the effect of peers without tracking and with only idiosyncratic differences in peers. They find that students of all ability levels do better with tracking. Interestingly, however, they find that students at the tracking cutoff (those just above are in high ability classes and those below are in low ability classes) do equally well, suggesting no peer effects conditional on tracking. However, when they look at the effects of small differences in peers induced by the randomization of peers, they find positive effects of having high ability peers.

${ }^{7}$ Because of the inclusion of individual fixed effects, the strategy relies on relating changes in student performance to changes in peer group over time; this approach is obviously infeasible when looking at post-school outcomes.

${ }^{8}$ Similar in spirit, Kramarz, Machin, and Ouazad (2009) use British data to distinguish the components of test scores and test score growth that are related to pupils, schools, and peers. They find that pupil heterogeneity is a more important determinant of achievement than school quality (although both are statistically significant). Peer effects are small but significant.
} 
Lavy and Schlosser (2007), Bifulco, Fletcher, and Ross (2010), and Gould, Lavy, and Paserman (2009). ${ }^{9}$ Gould et al. (2009) use idiosyncratic variation in the proportion of immigrants in elementary school grades in Israel and study the impact of immigrants on high school performance. Bifulco et al. (2010) use U.S. data from Add Health focusing on the effect of percent minorities and college educated mothers per cohort on the probability of dropping out of high school, attending college, and likelihood of smoking. In contrast to our study, they do not use school level administrative data and their principal focus is on the effect of minorities. Lavy and Schlosser (2007) use Israeli data to examine how idiosyncratic changes in gender composition affect elementary, middle, and high school performance. Once they establish that student outcomes are better in the presence of a higher fraction of girls, they then examine whether it is because of changes in the composition of the class (boys are worse behaved on average) or changes in the behavior of the individual students, using survey data of students and teachers. While similar in spirit, our work looks at a variety of peer characteristics and at a country with a very different institutional framework. Also, unlike Lavy and Schlosser, our outcome variables are post-school outcomes rather than in-school test scores.

\section{Empirical Methodology}

\section{A. Using Idiosyncratic Variation in Peer Characteristics}

Our general equation of interest is as follows:

$$
y_{i c s}=\alpha+\beta_{1} x_{i c s}+\beta_{2} x_{i c s}^{-i}+\beta_{3} g_{s c}+\sum_{c=1}^{15} \delta_{c} D_{c}+\lambda_{s c}+\varepsilon_{i c s}
$$

\footnotetext{
${ }^{9}$ Work by Ammermueller and Pischke (2009) uses data from six European countries and within school, across classroom variation for identification. The authors argue that classroom assignment in primary school is effectively random, and they find modestly large effects of peer effects on in-school exams.
} 
where $y_{i c s}$ is the outcome measure for individual $\mathrm{i}$ in cohort $\mathrm{c}$, in school $\mathrm{s}$. A cohort refers to all individuals who are in grade 9 in the same year whether or not they have the same year-of-birth. As is described in section 5 below, we have information on children from 15 cohorts. Outcomes are a function of the individual's own characteristics, $x_{i c s}$, which include gender, family size and its square, mother's education, an indicator for whether the child is firstborn, mother's age at birth and its square, and immigrant status. Also included are the mean characteristics of their peers (peers are defined as everybody in their grade except themselves), $x_{i c s}^{-i}$, which are the average age, the fraction female, and the average socioeconomic status as measured by mother's education. Our main coefficients of interest are those in $\beta_{2}$. We also control for the number of students in the grade in the school $\left(g_{s c}\right)$ and a full set of cohort dummies where $D_{c}$ is a dummy variable equal to 1 if the observation is from cohort c, and equal to zero otherwise. ${ }^{10} \lambda_{s c}$ refers to school effects that may or may not differ across cohorts; a key issue is the appropriate parameterization of $\lambda_{s c}$.

One possibility is to parameterize $\lambda_{s c}$ by including the mean value of student characteristics measured at the school level. ${ }^{11}$ In this case, we study the impact of

\footnotetext{
${ }^{10}$ The cohort dummies are not school-specific. All individuals in Norway who started school in the same year will have the same values for the cohort dummies.

${ }^{11}$ We sometimes refer to this as pseudo fixed effects as it is similar in spirit to including school fixed effects. Mundlak (1978) showed an equivalence between the fixed effects specification and a particular correlated random effects specification. This implies that estimating
}

$y_{i c s}=\alpha+\beta_{1} x_{i c s}+\beta_{2} x_{i c s}^{-i}+\beta_{3} g_{s c}+\sum_{c=1}^{15} \delta_{c} D_{c}+\lambda_{s}+\varepsilon_{i c s}$

using school fixed effects produces the same estimate of $\beta_{2}$ as estimating

$$
y_{i c s}=\alpha+\beta_{1} x_{i c s}+\beta_{2} x_{i c s}^{-i}+\beta_{3} g_{s c}+\sum_{c=1}^{15} \delta_{c} D_{c}+\lambda_{1} \bar{x}_{s}+\lambda_{2} \bar{x}_{s}^{-i}+\lambda_{3} \bar{g}_{s c}+\sum_{c=1}^{15} \eta_{c} \bar{D}_{c}+e_{i c s}
$$


variation in peer composition, conditional on the average peer composition over all cohorts in the school. By controlling for the average characteristics of children in the school across all cohorts, we are taking account of the fact that some schools may generally attract better students than others. The regression we estimate is then: $y_{i c s}=\alpha+\beta_{1} x_{i c s}+\beta_{2} x_{i c s}^{-i}+\beta_{3} g_{s c}+\sum_{c=1}^{15} \delta_{c} D_{c}+\lambda_{1} \bar{x}_{s}+e_{i c s}$

We cluster the standard errors by school to allow for arbitrary within-school correlations in the errors.

With this parameterization of $\lambda_{s c}$, we are assuming that, conditional on cohort dummies and average student characteristics in the school, peer characteristics in a particular grade are as good as randomly assigned. While we know there is sorting based on place of residence, this is not a problem so long as it does not change over time as it will then be picked up by the average school student characteristics. However, a key concern is the existence of trends over time in neighborhoods or schools that are correlated both with peer quality and student outcomes. ${ }^{12}$ For example, if a neighborhood/school is becoming "poorer" over time, the average peer quality and individual student performance will both be declining. If one does not take into account these differential changes over time, one might observe a spurious relationship between

without school fixed effects. In equation 3, the means of all variables from equation 2 are taken by school, and added as additional explanatory variables to the model. So $\bar{x}_{s}$ is the within-school mean of the individual characteristics, and $\bar{x}_{s}^{-i}$ is the within-school mean of the peer characteristic. $\bar{D}_{c}$ is then the proportion of individuals in a particular school that are in cohort c. Estimating (3) gives exactly the same $\beta_{2}$ coefficients as estimating equation (2) using school fixed effects. Given that, in our context, $\bar{x}_{s}=\bar{x}_{s}^{-i}$, equation (1) is very similar to equation (4) below and, in practice, the two strategies give very similar estimates.

${ }^{12}$ Note that national trends will be absorbed by the cohort dummies. 
peer quality and student performance. We therefore also use parameterizations of $\lambda_{s c}$ that allow for changes in school quality over time.

\section{$\underline{\text { School-Specific Trends }}$}

It is common in the literature to allow for school-specific trends (for example, Hoxby 2000) and this is the first approach we take. Given our estimation strategy, it is not feasible to directly add a linear trend for each school so we implement this in our set-up as follows: First we regress each individual characteristic, for example female, on school dummies and school dummies interacted with a linear cohort trend. We then calculate the fitted value of the characteristic for each school/cohort cell. This fitted value can be interpreted as the expected peer composition in the school for that cohort if composition changes follow a school-specific linear trend. We add these fitted values (one for each peer characteristic) to the specification in equation (4). In effect, this means we study the effects of variation in peer characteristics conditional both on the mean peer characteristics in the school, and conditional on the predicted peer characteristics for that cohort in the school, allowing for a school-specific linear trend.

\section{Moving Average Approach}

The second approach we take to allow for changes in school quality over time takes a much less parametric perspective. The intuition is as follows: instead of comparing across long periods of time and imposing a particular functional form on the trend, we narrow the comparison. For every year, we regress the performance of a student in that year on the characteristics of her peers, conditional on the average characteristics of other students in the school taken over that year and the two adjacent years (the one before and the one after). By construction, any deviation in peer 
characteristics from this 3-year average cannot be due to a linear trend over this 3-year period and can therefore be treated as idiosyncratic variation. ${ }^{13}$ We add the 3-year moving average of student characteristics as extra control variables in equation (4).

It is important to note, however, that this is an extremely restrictive comparison. To the extent that peers in neighboring years actually do have an effect on an individual's performance, we will underestimate the role of peers on student outcomes. As a result, we view this estimate as a lower bound on true peer effects. ${ }^{14}$

\section{B. Using Sibling Differences}

There is always a concern that the peer variation used in the methods above is not purely idiosyncratic and there may still remain (conditional) correlations between a child's family background and his peers. One way to rule out this possibility is by using sibling fixed effects. To do so, we restrict the sample to siblings who go to the same school. With sibling fixed effects, a potential source of bias is if, somehow, the "better" child in the family ends up in a cohort with a better peer group. The only plausible way in which this could happen is if parents manipulate school starting age so as to influence the peer group their children face. Our instrumental variables strategy (described below) deals with this possibility. Note that while the sibling fixed effects strategy has the advantage of ruling out any possibility that peer composition is correlated with family background characteristics, it has the disadvantage that one-child families are excluded from estimation (and when we split by sex we must omit families with fewer than two

\footnotetext{
${ }^{13}$ By necessity, we exclude cohorts 1 and 15 as they are not middle cohorts in any 3-cohort sequence.

${ }^{14}$ Our moving average strategy is somewhat similar to that used by Gould et al. (2009). They condition on the lag and the lead of the relevant peer variable, as well as the number of persons in the class. Their approach may have greater potential for bias; if the lead and lag are correlated with unobserved school characteristics, it is likely that the current value of the peer variable is as well.
} 
children of that sex). Thus, the estimation sample is somewhat unrepresentative and estimates are less precise because of the smaller sample sizes. Also, there is some risk that if peer quality is higher for one child in a family, this may correlate with other timevarying features of the school also being better. This is an issue because this strategy does not carefully control for school-level changes over time.

\section{Endogeneity of School Starting Age}

There is a potential endogeneity problem in equation (4) in that parents may strategically choose the starting age of their child in response to the peer composition of a particular cohort in a particular school. For example, a parent may hold back their child by a year if the child has friends that are not starting until a year later. Thus, while the peer composition in one's year-of-birth may be random (conditional on the school), the peer composition in one's grade may not be. ${ }^{15}$ To deal with this, we instrument the peer variables with what they would have been if everybody had started on time i.e. the peer characteristics of one's birth cohort. ${ }^{16}$ For completeness, we instrument all other variables with what they would have been if everybody started on time. For example, we instrument the cohort dummies with birth-year dummies. ${ }^{17}$ Additionally, we instrument the actual school starting age of the child with what it would have been if the child started on time.

\footnotetext{
${ }^{15}$ If everybody followed the administrative rule, all students in a particular grade would have the same year-of-birth.

${ }^{16}$ This instrumental variables strategy is similar in spirit to that of Hoxby and Weingarth (2006) who use characteristics of peers who are assigned to a school as instruments for the actual peer characteristics in the school.

${ }^{17}$ Our instrumental variables strategy partially motivates the specification we use i.e. equation (4) rather than equation (2). It would be impossible to instrument $1000+$ school-specific trends but it is easily feasible to instrument the controls for the fitted peer variables with what they would be if everyone started on time.
} 


\section{Norwegian School Structure}

In Norway, compulsory education is free; since 1997, schooling has been compulsory from age 6 to $16\left(10^{\text {th }}\right.$ grade $)$. However, the cohorts we consider faced a school starting age of 7 with 9 years of compulsory schooling. Schools are run by the local municipality and there is no tracking by ability during the years of compulsory schooling. ${ }^{18}$ School attendance is based on your place of residence, and the rules that pupils attend the school in their catchment area are strictly enforced. ${ }^{19}$

The focus of our study is on lower secondary school, which is comprised of grades 7-9. The mandatory school system in Norway is split into primary schools (grades 1-6) and lower secondary schools (grades 7-9). Most pupils attended separate primary and secondary schools, while about 20 percent went to combined primary and secondary schools (Hægeland, Raaum, and Salvanes, 2005). Most combined schools are in rural areas and have a small number of students.

\footnotetext{
18 There are very few private schools in Norway and only about $2 \%$ of all pupils attend them.

${ }^{19}$ At the high school level there are differences across municipalities and across time regarding the degree of school choice but this does not occur until students have completed lower-secondary school.
} 
Unlike in the United States, students stay with the same group of students for all their classes in the day and throughout the year. Different teachers are allocated to each class based on field. There is essentially no grade retention in Norway (Strøm, 2004), suggesting that all students that start the same year also graduate the same year. Furthermore, 95.3 percent of the students lived in the graduation municipality for all three years in the lower secondary school, suggesting very little mobility.

\section{Data}

Our primary data source is the Norwegian Registry Data, a linked administrative dataset that covers the population of Norwegians up to 2006 and is a collection of different administrative registers such as the education register, family register, and the tax and earnings register. These data are maintained by Statistics Norway and provide information about educational attainment, labor market status, earnings, and a set of demographic variables (age, gender) as well as information on families. ${ }^{20} \mathrm{We}$ focus on cohorts born between 1959 and $1973 .^{21}$

The school data come from the Norwegian education register. Each school in Norway was legally required to report when a student graduated from primary and secondary school. As a result, we know from which school each pupil graduated.

\section{Peer Characteristics}

There are a number of ways peers in middle school could affect the outcomes of an individual. Teachers may adapt the way they teach to be most appropriate to the

\footnotetext{
${ }^{20}$ See Møen, Salvanes and Sørensen [2004] for a description of these data.

${ }^{21}$ We exclude a small number of individuals who started school more than 1 year early or 1 year late.
} 
group as a whole, peers may help the other students in the class by providing assistance or acting as role models, and the characteristics of peers may influence the self-esteem of students in the class. Because there is so little understanding of the mechanisms for peer effects, it is very difficult to know the appropriate measures of peer quality/characteristics.

In our model, we use three measures of peer characteristics. ${ }^{22}$ The first is the fraction of girls in the grade. Evidence suggests that girls are better behaved and cause fewer disruptions in the classroom (Lavy and Schlosser, 2007). Theoretical work by Lazear (2001) suggests that having less-disruptive students in the class has beneficial effects on all students in the class; in this case, a higher fraction of girls in the classroom would have a positive effect on outcomes of both boys and girls. However, a higher fraction of girls in the class could also provide greater distraction for teenage boys. This could cause differential effects by gender, with more girls having a negative impact on outcomes of boys, and, symmetrically, more boys having a negative impact on outcomes of girls. Ultimately, this is an empirical question.

Our second measure is the average age in the classroom. In earlier work, we documented an effect of school starting age on the outcomes of adults; one of the most notable findings was the effect on teenage childbearing. (See Black, Devereux and Salvanes, 2008.) Women who start school younger are more likely to have children as teenagers. One possible explanation for this is the influence of peers; girls who start school younger have a relatively older peer group and may be influenced by their peers'

\footnotetext{
${ }^{22}$ In the peers literature, researchers often focus on the effects of peer ability on outcomes (see Lavy et al. 2009 for a recent example). We have no measure of ability and so focus on the effects of pre-determined peer characteristics.
} 
behavior. ${ }^{23}$ This would imply that, conditional on own age, having older peers increases the likelihood of teen pregnancy. Peer age could also affect other outcomes by changing the average maturity in the classroom. In this case, we would expect that having older peers would lead to better academic outcomes. Because grade repetition is extremely rare in Norway, the average school starting age of peers determines the average age of peers in $9^{\text {th }}$ grade and we use both terms interchangeably.

Our final measure of peer characteristics is the average mother's education of the students in the grade, which we use as a proxy for socioeconomic status. ${ }^{24}$ In general, we would expect peers with higher socio-economic status to have positive spillovers. Early work by Evans, Oates, and Schwab (1992) studies the relationship between the presence of disadvantaged peers and teenage pregnancy; they find a significant, although small, relationship between the two which disappears when they control for selection into schools using a simultaneous equations model and city-level characteristics as instruments.

Peers are measured as the group of students in your grade and school in the $9^{\text {th }}$ grade. There may be substantial persistence in peers over time. As a result, these peer measures represent not only the peers an individual faces in the $9^{\text {th }}$ grade but, to the extent these are the same peers they have had throughout their educational experience

\footnotetext{
${ }^{23}$ Cascio and Schanzenbach (2007) use variation in peers induced by the randomization to classes in the Tennessee STAR experiment to examine the role of relative age on the performance of students in the $8^{\text {th }}$ grade as well as whether or not the individual takes the SAT or ACT exam. The authors find little effect of relative age once controlling for the age of the individual; however, when the data is decomposed by family background, there is some effect of relative age on the outcomes of more disadvantaged students.

${ }^{24}$ We have also tried creating a socio-economic index by regressing an individual's educational attainment on dummies for family size, mother's education, father's education, whether the person is an immigrant, and family income in 1978, 1983, and 1988 and using the predicted value as a socioeconomic index. We found very similar results for this variable to those we report for mother's education.
} 
(and will continue to have into the future), the estimated effect represents the cumulative effect of peers throughout the educational experience.

As described below, we create instruments for these peer variables using the individuals who were born in the same cohort and went to the same school (whether or not they finished in the same year).

The variation we are using is that in peer characteristics, conditional on average student characteristics in the school and on cohort fixed effects. To alleviate concerns about insufficient variation in our variables of interest, we have calculated the fraction of total variation in peer characteristics that is explained by these control variables using the $\mathrm{R}^{2}$ from regressions with the peer characteristics as dependent variables. In the specification that allows for school-specific linear trends, the percentage explained ranges from $17 \%$ (percentage female) to $46 \%$ (average age) to about $91 \%$ (mother's education). With the moving average controls, the percentages are higher at $35 \%, 51 \%$, and $92 \%$ respectively. This suggests there is still substantial variation left in these variables even after including cohort fixed effects and detailed controls for school characteristics. ${ }^{25}$

\section{Outcome Variables}

$\underline{\text { IQ Scores }}$

The IQ score data is taken from the Norwegian military records from 1980 to 2005. Before young men enter the service, their medical and psychological suitability is assessed; this occurs for the great majority between their eighteenth and twentieth

\footnotetext{
${ }^{25}$ The $10^{\text {th }}$ percentile values of the peer variables are $.41,7.2$, and 8.8 for the percentage female, the average age, and the average mother's education, while the $90^{\text {th }}$ percentile values are $.56,7.4$, and 10.9 respectively.
} 
birthday ${ }^{26}$ In Norway, military service is compulsory for every able young man; as a result, we have military data for men only. ${ }^{27}$

The IQ measure is the mean score from three IQ tests -- arithmetic, word similarities, and figures (see Sundet et al. [2004, 2005] and Thrane [1977] for details). The arithmetic test is quite similar to the arithmetic test in the Wechsler Adult Intelligence Scale (WAIS) [Sundet et al. 2005; Cronbach 1964], the word test is similar to the vocabulary test in WAIS, and the figures test is similar to the Raven Progressive Matrix test [Cronbach 1964]. The IQ score is reported in stanine (Standard Nine) units, a method of standardizing raw scores into a nine point standard scale that has a discrete approximation to a normal distribution, a mean of 5 , and a standard deviation of $2 .{ }^{28} \mathrm{We}$ have IQ scores on about $84 \%$ of the relevant population of men in Norway.

\section{Teenage Childbearing}

We construct our teenage childbearing variable by restricting the sample to women aged at least 36 in 2006 and denoting a teen birth if they have a child that is aged at least 16 in 2006 who was born before the woman was aged $20 .{ }^{29}$ Approximately 9.7\% of our sample of women had a child before age 20 .

\section{Educational Track}

At the end of $9^{\text {th }}$ grade (the end of compulsory education), an individual chooses (conditional on grades) whether to enter the academic track, the vocational track, or drop out of school. The academic track (or general track, also called gymnasium) is a three

\footnotetext{
${ }^{26}$ We add a control for the year the test was taken in the IQ score specifications.

${ }^{27}$ Norway has mandatory military service of between 12 and 15 months (fifteen in the Navy and twelve in the Army and Air Force) for men between the ages of 18.5 (17 with parental consent) and 44 (55 in case of war). However, the actual draft time varies between six months and a year, with the rest being made up by short annual exercises.

${ }^{28}$ The correlation between this IQ measure and the WAIS IQ has been found to be .73 (Sundet et al., 2004).

${ }^{29}$ In order to know whether a woman had a teen birth we need to observe both the mother and child in the administrative panel. The result is that the cohorts we use are born between 1963 and 1970.
} 
year high school education preparing for college. Students who complete this track are then eligible for college enrolment. In contrast, the vocational track consists of vocational training and, although it generally takes 3 years, can require as little as one year in school followed by an apprenticeship. Upon completion, the individual receives a certificate of proficiency within their area of specialization. ${ }^{30}$ Using OLS and controlling for family background factors, there is an earnings premium of almost $20 \%$ to taking the high school track rather than the vocational track

\section{Labor Market Variables}

Earnings are measured as total pension-qualifying earnings reported in the tax registry in 2005. These are not topcoded and include labor earnings, taxable sick benefits, unemployment benefits, parental leave payments, and pensions. We identify full time workers (defined as $30+$ hours per week) using the fact that our dataset identifies individuals who are employed and working full time at one particular point in the year (in the $2^{\text {nd }}$ quarter in the years $86-95$, and in the $4^{\text {th }}$ quarter thereafter). ${ }^{31}$ About $71 \%$ of our male sample are employed full time in 2005 ; the equivalent figure for women is $48 \%$.

Table 1 presents summary statistics for our sample.

6. Results

\section{A. Balancing Tests}

\footnotetext{
${ }^{30}$ Overall, $74 \%$ of girls follow the academic track, $20 \%$ the vocational track, and the remaining $6 \%$ drop out after compulsory schooling. For men, the numbers are $45 \%$ academic, $48 \%$ vocational, and $7 \%$ drop out.

${ }^{31}$ An individual is labelled as employed if currently working with a firm, on temporary layoff, on up to two weeks of sickness absence, or on maternity leave.
} 
Before presenting our results, we first examine the validity of our identifying assumptions. The basic notion is that, conditional on the controls, variation in peer characteristics should be "as if random" and, hence, should not be correlated with predetermined characteristics of children such as their family background variables. To examine this issue, we regress mother's education and other predetermined variables on the peer characteristics using the specifications described earlier but excluding the predetermined variables (i.e. all the individual control variables) from these regressions. To the extent that the presence of these variables in the main specifications reduces bias, these balancing tests provide a worst-case assessment of the situation. The estimates reported are from IV models where the actual peer variables are instrumented by what they would be if everyone started school on time. The estimates are in Appendix Table 1.

The first panel of Appendix Table 1 is the quasi fixed effects specification that includes controls for the mean values of the peer variables for the school. The second panel adds controls for the school-specific trends by adding the predicted value of the peer variables given a linear school-specific trend. The third panel instead adds the 3-year moving average of the peer characteristics as controls.

Note that in all 3 panels but particularly in panels 2 and 3 , there is a tendency for a strong negative coefficient on, say, average mother's education of peers when the dependent variable is mother's education. This results from small sample bias and is similar to the short panel bias that occurs in dynamic fixed effects models. To see why, consider the $3^{\text {rd }}$ panel where we control for the 3 -year moving average of mother's education in the school. If conditional on this, your peer average maternal education is high, your own maternal education will tend to be low (as both your maternal education 
and that of your peers go into forming the moving average). The $4^{\text {th }}$ panel attempts to correct for this bias by forming the school means and the moving averages leaving out observation i. For the most part, the large negative relationships disappear in the $4^{\text {th }}$ panel.

Unsurprisingly, the proportion of peers that are female is unrelated to any predetermined variable in any specification (except a negative relationship with sex as a result of small sample bias in the first 3 panels). For the other two peer variables, the results show a clear pattern of improvement from panel 1 to panel 4 . The quasi fixed effects specification in panel 1 is clearly inadequate for studying average mother's education of peers. However, any positive relationship between this and a child's own characteristics disappear once moving averages are included as controls. Average age of peers is unrelated to all variables except first-born status in the trends and moving average specifications. We have no idea why. Overall, the conclusion is that all specifications are likely to be valid when studying the effect of proportion female. However, when studying the other two peer variables, we can have far more confidence in the specifications with trends and moving averages.

\section{B. Education Track}

The first outcome we look at is the education track; Table 2 shows estimates where the dependent variable is whether the student follows an academic high school track after completing compulsory schooling, estimated by gender. When we look at the coefficients for the individual level characteristics for both boys and girls, it is not surprising that first-borns and students with higher maternal education are more likely to 
follow this track. ${ }^{32}$ The OLS impact of school starting age is negative but the IV estimates are positive and suggest that starting school a year later increases this probability by about $1 \%$ for boys and $.7 \%$ for girls. ${ }^{33}$

The only peer variable that appears to influence educational track choice is the fraction of the class that is female, and this is only true among boys - more girls make it less likely that any particular boy does the academic track. To get a sense of the magnitude of these effects, going from $40 \%$ girls to $60 \%$ girls reduces the probability by about .01 from a baseline of about .5 . The other peer characteristics are all small and statistically insignificant with the exception that maternal education has a statistically significant positive effect in the quasi fixed effects specification. However, this result disappears once we allow for time-varying school quality using either the trends or the moving average. None of the other peer characteristics appears important for either sex. Almost all estimates are insignificant and the peer effects are much smaller than the analogous direct effects, despite the fact that the standard deviations of the individual characteristics are much higher than those of the peer characteristics.

\section{Completed Years of Education}

For the remaining outcome variables, we report only the IV estimates for the peer characteristics. Estimates for completed years of education are in Table 3. These results reveal an interesting dichotomy. A higher proportion of girls has a negative effect on completed education of boys. However, if anything, more girls have a positive effect on

\footnotetext{
${ }^{32}$ See Black, Devereux, Salvanes (2005a, 2005b) for analysis of the effects of birth order and maternal education in Norway.

${ }^{33}$ The change in sign from OLS to IV results from the fact that, in the IV specification, we instrument child age with what it would have been if the child had started school at the age specified by the administrative rule. Late school starters appear to be negatively selected and this leads to large negative OLS age effects.
} 
education of girls so it appears that each sex benefits from having more of their own gender. The size of the effect for boys is about -.2 which implies that going from $40 \%$ to $60 \%$ girls would reduce average completed education of boys by about .04 . The effects of peer maternal education seem equally small for boys and girls at about .03 - the coefficient is slightly larger and more significant for girls but the difference is quite small.

\section{Teenage Childbearing}

Motherhood at young ages has been associated with many long-term economic and health disadvantages such as lower education, less work experience and lower wages, welfare dependence, lower birth weights, higher rates of infant mortality, and higher rates of participation in crime (Ellwood, 1988; Jencks, 1989; Hoffman, and Furstenberg, 1993; Kiernan, 1997). There is an ongoing debate as to the extent that these adverse effects of teen childbearing are truly caused by having a teen birth rather than reflecting unobserved family background differences. (See Hotz, McElroy, Sanders 2005 for an example). However, as a policy matter, efforts to reduce the rate of teen childbearing are often considered as a strategy to improve the life chances of young women.

Table 3 presents the results of 2SLS linear probability models of teenage childbearing. The fraction female is negative and statistically significant in both specifications. The effect size is about -.025 which implies that if a class went from $40 \%$ female to $60 \%$ female, the resultant probability of a woman giving birth as a teen falls by -.005. Given that the baseline probability is about .1, and this is a large change in class composition, this seems to be a relatively modest sized effect. 
We hypothesized that higher peer age may lead to more teen pregnancies. However, we find very small and statistically insignificant coefficients in the two specifications, suggesting that the effect of starting school later on teen pregnancy comes primarily from absolute rather than relative age effects. There is also little evidence that peer maternal education matters for teen childbearing.

\section{E. IQ Test Scores}

Table 3 has estimates where the dependent variable is IQ test scores for men at around age 18. The dependent variable is measured in stanine units with a standard deviation being approximately 2 stanines. Here, we find some evidence that having classmates with higher maternal education has a positive effect. However, this effect is

only statistically significant in the trends specification. The maternal education effect of about .03 suggests that even increasing average maternal education of peers by 1 year would only increase IQ scores of a student by about $1.5 \%$ of a standard deviation. This is surely a modest effect.

\section{F. Labor Market Outcomes in 2005}

Table 3 also has estimates from a 2SLS linear probability model of whether or not the individual works full time in 2005 and 2SLS regression of their log earnings in 2005 on our measures of peer characteristics. Because of the fundamentally different labor market experiences of men and women, we have omitted estimates that pool genders and simply report results separately by sex. The only peer variable that matters is fraction female. Once again we have the contrasting effects that more girls appear to increase full- 
time participation for women but reduce it for men (although the male estimates are not quite statistically significant). The finding is very similar for earnings with more girls being beneficial to women but having an adverse, although statistically insignificant, effect on men.

\section{Results using sibling fixed effects}

The sibling fixed effects estimates are presented in Table 4. Because this method requires two children of the same sex per family, the sample sizes are much smaller than before and the standard errors are correspondingly higher. As a result, there are very few statistically significant peer effects. However, the same general pattern that was seen in Table 3 is present here - a higher fraction of female peers generally improves outcomes of girls and hurts outcomes of boys.

\section{Recent Cohorts}

We also have information on children who start school between 1982 and 1996 (Oslo from 1985) and who finish school lower secondary school between 1991 and 2006. ${ }^{34}$ Because these are more recent cohorts, we do not have labor market information or even completed education for most of them, and so we report estimates for high school track.

For more recent cohorts who started school between 1992 and 1996, we also have information on $10^{\text {th }}$ grade math scores. Data are collected by the Directorate for Primary and Secondary Education. Scores are awarded on a scale from one to six, with higher

\footnotetext{
34 There is no information on lower secondary school attended for any person who finished lower secondary school in 1990 so this cohort is excluded from all analysis in this paper.
} 
scores indicating better performance. We focus on marks in math assessed throughout the year (Math Score1) as well as performance in the final written examination at the end of 10th grade (Math Score2). The final exam mark is based on a five-hour test in math. All pupils in the country do the same (subject-specific) test, and pupils are randomly allocated to subjects such as math, English and Norwegian. ${ }^{35}$ While the grading for the final exam is anonymous and done by external examiners, the assessment throughout the year is done by teachers. We use these test scores to compare the results generated with our datasets (pooled and then by gender, for comparability) to those for in-school scores in the existing literature. ${ }^{36}$

The main estimates are in Table 5. As in the earlier cohorts, we find that a higher fraction of women reduces the proportion who do the academic high school track and that this effect is only significant for boys. The magnitude is very similar in these cohorts to that for the earlier cohorts. The sibling fixed effects estimates in Table 7 also show the negative effect of more females on academic track. Interestingly, our earlier findings about the impact of girls also hold for cohorts in which the educational attainment of girls had increased relative to that of boys.

On the other hand, while the magnitude and statistical significance of the estimates varies by specification, both sets of estimates suggest that math scores are higher when there is a higher fraction of girls. We find this result both for in-class assessment (Score1) and for exam results (Score2). Given that the standard deviation of math test scores is 1.1 (see Appendix Table 2), the coefficient values of between .1 and .27 from the various specifications imply that a $10 \%$ increase in the proportion of girls

\footnotetext{
${ }^{35}$ Because of the fact that the test taken (English, Norwegian, or Math) is randomized so students only take one of these 3, we only have information on Math test scores for about one third of the sample.

${ }^{36}$ Appendix Table 2 contains descriptive statistics for the sample of recent cohorts.
} 
would lead to between $.9 \%$ and $2.5 \%$ of a standard deviation increase in math test scores. This result is both qualitatively and quantitatively consistent with the findings of Lavy and Schlosser (2007) for Israel, Kang (2007) for South Korea, and Hoxby (2000) for the United States. The findings for high school track and math test scores taken together suggest the possibility that while having more girls in a grade increases test scores, it may have other detrimental effects (particularly on boys).

In terms of the other peer variables, there is some evidence that having older classmates reduced the probability that boys follow the high school track, but this is not consistent across specifications. Similarly, there is a little evidence that higher maternal education of peers leads to higher math test scores.

Table 6 reports sibling fixed effects estimates for the recent cohorts. We do not split by gender because the standard errors become sufficiently high as to make the estimates quite uninformative. Also, we do not report estimates for Math Score2 as there are very few cases where we have scores for two people in the same family. The sibling fixed effects estimates are less precisely estimated but the coefficients on proportion female are quite similar to those in Table 5.

\section{Non-Linear Effects}

Our base specification allows for linear effects of the average characteristic over all peers, excluding the individual him/herself. It also allows for parameter heterogeneity by gender but not along other dimensions. However, in addition to the homogenous effect linear-in-means model, we have also estimated more flexible specifications that enable us to test for non-linear and heterogeneous effects. 
To test for non-linear effects, we created 3 categories for each peer variable. For proportion female, we categorized classes as being less than $40 \%$ female, between 40 and $60 \%$ female, or being more than $60 \%$ female. We created similar splits for the other two peer variables. ${ }^{37}$ In all cases, there was no evidence of these types of non-linear effects. ${ }^{38}$

An alternative approach to non-linearities is to allow outcomes to depend on a measure of the variability of peer characteristics in addition to the mean level. We have implemented this by adding the standard deviation of mothers' education in the grade and the standard deviation of age in the grade as additional peer variables. As before, we instrument these variables with what they would have been if everybody had started school on time. The estimates are reported in Table 7. We find no effect of the standard deviation of child age. However, while not all estimates are statistically significant, there is a clear suggestion that a lower standard deviation of mothers' education produces better outcomes. ${ }^{39}$ The coefficient implies that a one standard deviation increase in the standard deviation of mothers' education leads to a fall in completed education of about .02 of a year on average. This would seem to be a fairly small effect. Also, the coefficients on average maternal education of peers are generally higher in Table 7 than in Table 3 because the mean and standard deviation of maternal education are positively correlated. The increases in the coefficients are small and remain consistent with a very modest role of average peer socio-economic status.

\footnotetext{
${ }^{37}$ These non-linearities allow for evidence of threshold, or "epidemic" effects (Crane 1991).

${ }^{38} \mathrm{We}$ note, however, that the standard errors become quite high in some of our sample splits so that differences in coefficients would have to be fairly large for us to reject the linear model.

${ }^{39}$ Note that we control for grade size and have also checked that the estimates are robust to adding additional controls for the square root and the square of the number of students in the grade in the school. Thus, our estimates are not contaminated by correlations between the standard deviation of maternal education and the size of the grade.
} 
To test for heterogeneity, we carried out separate regressions of the linear-inmeans peers model by different types of individuals. We found no evidence of heterogeneity when we split the sample by low, medium, or high mother's education. Similarly splits by whether first born, whether started school late, whether had a birth month that predicted being relatively old for the class, or whether was in a large school or a small school all showed no evidence of heterogeneous effects. It is plausible that school peer effects might be larger for teenagers who are only children as peer influence does not compete with the influence of siblings. However, we also found no evidence for this type of heterogeneity.

We also estimated some specifications that allowed for both non-linearity and heterogeneous effects. For example, we allowed the effects of low, median, or high mothers education to vary by whether the peers were male or female. Once again, there was no evidence to reject the simple linear-in-means constant effects model.

\section{Conclusions}

Public policies are affected by, and often rely on, the fact that an individual's peers influence his/her behavior. Despite this, the evidence on the existence of peer effects has been inconclusive. In this paper, we have investigated the importance of three peer characteristics in lower secondary school on subsequent outcomes of students. We have two main findings. The first is that average age of peers and their socio-economic status (as proxied by mother's education) have very little effect on long run outcomes. The non-importance of average age of peers implies that relative age effects cannot 
explain the finding of Black, Devereux, and Salvanes (2008) that girls who start school younger are more likely to have teen births.

The second main finding is that the proportion of girls appears to matter and in a way that differs by gender - a higher proportion of girls is generally good for the longer run outcomes of girls but bad for boys. This is despite the existing evidence that suggests that a higher proportion of girls improves shorter run, in-school test scores for both boys and girls. Importantly, because we are able to look at in-school test scores for a subsample of our data, we are able to demonstrate that these test score gains are true in our data as well; short term test score gains due to a higher fraction of girls are offset by the longer run negative effects of a higher fraction of girls on boys. Our results suggest that a higher proportion of girls reduces the probability teenage boys continue onto an academic high school track and reduces completed years of schooling. It appears that, at least for teenagers, peer sex composition has complicated effects. 


\section{References}

Ammermueller, Andreas and Jorn-Steffen Pischke. (2009). "Peer Effects in European Primary

Schools: Evidence from PIRLS,” Journal of Labor Economics, 27, July, 315-348.

Bifulco,Robert, Jason Fletcher, and Stephen Ross. (2010). “The Effect of Classmate Characteristics on Individual Outcomes: Evidence from the Add Health," memo, Yale University.

Black, Sandra E., Paul J. Devereux, and Kjell G. Salvanes. (2005a). "Why the Apple Doesn't Fall Far: Understanding Intergenerational Transmission of Human Capital." American Economic Review, 95(1), 437-49.

Black, Sandra E., Paul J. Devereux, and Kjell G. Salvanes. (2005b). "The More the Merrier? The Effects of Family Size and Birth Order on Children's Education," Quarterly Journal of Economics, CXX, 669-700.

Black, Sandra E., Paul J. Devereux Paul and Kjell G. Salvanes,(2008). "Too Young to Leave the Nest? The Effects of School Starting Age,” NBER Working Paper No. 13969.

Carrell, Scott E., Richard L. Fullerton, and James E. West. (2009). "Does Your Cohort Matter? Measuring Peer Effects in College Achievement," Journal of Labor Economics, 27(3)439-464.

Cascio, Elizabeth and Diane Whitmore Schanzenbach. (2007). "First in the Class? Age and the Education Production Function,” NBER Working Paper No. 13663.

Coleman, James. et al. (1966). Equality of Educational Opportunity, Washington, DC: U.S. Government Printing Office.

Crane, Jonathan. (1991).“The Epidemic Theory of Ghettos and Neighborhood Effects on Dropping Out and Teenage Child Bearing.” American Journal of Sociology,, 96, 122659.

Cronbach, Lee J.(1964). Essentials of Psychological Testing, 2nd Edition, London, UK: Harper and Row.

Duflo Esther, Pascaline Dupas and Michael Kremer. (2008). "Peer Effects and the Impact of Tracking: Evidence from a Randomized Evaluation in Kenya,".

Elder, Todd E., and Darren H. Lubotsky.(2009). “Kindergarten Entrance Age and Children's Achievement: Impacts of State Policies, Family Background, and Peers," Journal of Human Resources, 44(3), 641-683.

Ellwood, D. (1988). Poor Support, New York, NY: Basic Books. 
Epple, Dennis and Richard E. Romano. "Peer Effects in Education: A Survey of the Theory and Evidence." Handbook of Social Economics, Benhabib, Bisin, and Jackson, Editors. Forthcoming.

Evans, William N., Wallace E. Oates, and Robert M. Schwab. (1992). "Measuring Peer Group Effects: A Study of Teenage Behavior," Journal of Political Economy, 100(5), 966-991.

Gould, Eric, Victor Lavy and Daniele Paserman. (2009). "Does Immigration Affect the Long Term Educational Outcomes of Natives? Quasi-Experimental Evidence," Economic Journal, 119(540), 1243-1269.

Hægeland, T., O. Raaum og K.G. Salvanes. (2005). "Pupil achievement, school resources and family background," IZA dp 1459.

Hanushek, Eric, John Kain, Jacob Markman and Steven Rivkin. (2003). "Does Peer Ability Affect Student Achievement?," Journal of Applied Econometrics, 18(5),, 527-544.

Hoffman, S., Foster, E., and Furstenberg jr., F. (1993). "Reevaluating the Costs of Teenage Childbearing," Demography, 30(1), 1-13.

Hotz, V. J., McElroy, S., and Sanders S. (2005). "Teenage Childbearing and its Life Cycle Consequences: Exploiting a Natural Experiment," Journal of Human Resources,40(3), 683-715.

Hoxby, Caroline. (2000). "Peer Effects in the Classroom: Learning from Gender and Race Variation,” NBER Working Paper No. 7867.

Hoxby, Caroline and Gretchen Weingarth. (2006). "Taking Race out of the Equation: School Reassignment and the Structure of Peer Effects," Working Paper, Harvard University.

Jencks, C. (1989). “What Is the Underclass-and Is It Growing?” Focus, 12, 14-26.

Kang, Changhui. (2007). "Classroom Peer Effects and Academic Achievement: QuasiRandomization Evidence from South Korea," Journal of Urban Economics, 61, 458-495.

Kiernan, K. (1997). "Becoming a Young Parent: A Longitudinal Study of Associated Factors," British Journal of Sociology, 48, 406-28.

Kramarz, Francis, Stephen Machin, and Amine Ouazad. (2009). "What Makes a Test Score? The Respective Contributions of Pupils, Schools and Peers in Achievement in English Primary Education," CEE DP 102.

Lavy, Victor and Analia Schlosser. (2007). "Mechanisms and Impacts of Gender Peer Effects at School," NBER Working Paper No. 13292. 
Lavy, Victor, Olmo Silva, and Felix Weinhardt. (2009). "The Good, the Bad and the Average: Evidence on the Scale and Nature of Ability Peer Effects in Schools," NBER Working Paper No. 15600.

Lazear, Edward "Education Production. (2001)." Quarterly Journal of Economics, 116(3), 777803.

Manski, Charles. (2000). "Economic Analysis of Social Interactions" Journal of Economic Perspectives, .

Møen, J., Salvanes K. and Sørensen E. (2004). 'Documentation of the Linked EmpoyerEmployee Data Base at the Norwegian School of Economics', Mimeo, The Norwegian School of Economics and Business Administration.

Moffitt, Robert. (2001). "Policy Interventions, Low-Level Equilibria, and Social Interactions" in Social Dynamics, Steven Durlauf and Peyton Young, Editors, Cambridge:MIT Press.

Mundlak, Yair. (1978). "On the Pooling of Time Series and Cross Section Data," Econometrica, 46(1),69-85.

Sacerdote, Bruce. (2001). "Peer Effects with Random Assignment: Results for Dartmouth Roommates," Quarterly Journal of Economics, 116(2), 681-704.

Sacerdote, Bruce. (2008). "Peer Effects in Education: How Might They Work, How Big are They, and How Much Do We Know Thus Far?" mimeo Darthmouth College.

Strøm, B. (2004). "Student Achievement and Birthday Effects", memo, University of Trondheim.

Sundet, Martin Jon, Dag G. Barlaug, and Tore M. Torjussen. (2004). "The End of the Flynn Effect? A Study of Secular Trends in Mean Intelligence Test Scores of Norwegian Conscripts During Half a Century," Intelligence, XXXII, 349-362.

Sundet, Jon Martin, Kristian Tambs, Jennifer R. Harris, Per Magnus, and Tore M. Torjussen. (2005). "Resolving the Genetic and Environmental Sources of the Correlation Between Height and Intelligence: A Study of Nearly 2600 Norwegian Male Twin Pairs," Twin Research and Human Genetics, VII, 1-5.

Thrane, Vidkunn Coucheron.1977). "Evneprøving av Utskrivingspliktige i Norge 1950-53," Arbeidsrapport nr. 26, Oslo:INAS.

Zimmerman, David J. (2003). "Peer Effects in Academic Outcomes: Evidence from a Natural Experiment," Review of Economics and Statistics, 85(1), 9-23. 
Table 1: Summary Statistics

\begin{tabular}{|c|c|c|}
\hline Individual Characteristics & Girls & Boys \\
\hline Educational Attainment & $\begin{array}{l}12.58 \\
(2.59)\end{array}$ & $\begin{array}{l}12.35 \\
(2.49)\end{array}$ \\
\hline Mother's Education & $\begin{array}{c}9.81 \\
(2.46)\end{array}$ & $\begin{array}{c}9.84 \\
(2.48)\end{array}$ \\
\hline Mother's Age at Birth & $\begin{array}{l}26.98 \\
(5.91)\end{array}$ & $\begin{array}{l}26.97 \\
(5.90)\end{array}$ \\
\hline Family Size & $\begin{array}{c}3.11 \\
(1.33)\end{array}$ & $\begin{array}{l}3.10 \\
(1.32)\end{array}$ \\
\hline Fraction Firstborn & $\begin{array}{l}.39 \\
(.49)\end{array}$ & $\begin{array}{l}.39 \\
(.49)\end{array}$ \\
\hline Immigrant & $\begin{array}{l}.02 \\
(.14)\end{array}$ & $\begin{array}{l}.02 \\
(.13)\end{array}$ \\
\hline Fraction Students Starting On Time & $\begin{array}{c}.947 \\
(.224)\end{array}$ & $\begin{array}{l}.936 \\
(.244)\end{array}$ \\
\hline School Starting Age & $\begin{array}{l}7.26 \\
(.31)\end{array}$ & $\begin{array}{l}7.28 \\
(.32)\end{array}$ \\
\hline Expected School Starting Age & $\begin{array}{l}7.25 \\
(.28)\end{array}$ & $\begin{array}{l}7.25 \\
(.28)\end{array}$ \\
\hline Fraction doing Academic Track in High School & $\begin{array}{l}.74 \\
(.44)\end{array}$ & $\begin{array}{l}.45 \\
(.50)\end{array}$ \\
\hline Fraction doing Vocational Track & $\begin{array}{l}.20 \\
(.40)\end{array}$ & $\begin{array}{l}.47 \\
(.50)\end{array}$ \\
\hline Fraction Having a Child as a Teenager & $\begin{array}{l}.097 \\
(.30)\end{array}$ & \\
\hline IQ Test Score & & $\begin{array}{c}5.2 \\
(1.8)\end{array}$ \\
\hline \multicolumn{3}{|l|}{ School/Peer Characteristics } \\
\hline \# of Students in Grade & $\begin{array}{l}100 \\
(51)\end{array}$ & $\begin{array}{l}100 \\
(51)\end{array}$ \\
\hline Average Age & $\begin{array}{l}7.3 \\
(.07)\end{array}$ & $\begin{array}{l}7.3 \\
(.07)\end{array}$ \\
\hline Average Female & $\begin{array}{l}.49 \\
(.07)\end{array}$ & $\begin{array}{l}.49 \\
(.07)\end{array}$ \\
\hline Average Mother's Education & $\begin{array}{l}9.82 \\
(.90)\end{array}$ & $\begin{array}{l}9.82 \\
(.90)\end{array}$ \\
\hline $\begin{array}{l}\mathrm{N} \\
\text { Number of Schools }\end{array}$ & $\begin{array}{c}434,001 \\
1,235\end{array}$ & $\begin{array}{c}450,902 \\
1,235\end{array}$ \\
\hline
\end{tabular}

Standard deviations in parentheses. 
Table 2: Effect of Peers on Educational Track

(Dummy $=1$ if Academic Track)

\begin{tabular}{|c|c|c|c|c|c|c|c|c|c|c|c|c|}
\hline & \multicolumn{6}{|c|}{ Men } & \multicolumn{6}{|c|}{ Women } \\
\hline & \multicolumn{2}{|c|}{ School Means } & \multicolumn{2}{|c|}{$\begin{array}{c}\text { School Means } \\
\text { and Trends }\end{array}$} & \multicolumn{2}{|c|}{$\begin{array}{c}\text { School Means } \\
\text { and } \\
\text { Moving Average }\end{array}$} & \multicolumn{2}{|c|}{ School Means } & \multicolumn{2}{|c|}{$\begin{array}{c}\text { School Means } \\
\text { and Trends }\end{array}$} & \multicolumn{2}{|c|}{$\begin{array}{c}\text { School Means } \\
\text { and } \\
\text { Moving Average }\end{array}$} \\
\hline & OLS & IV & OLS & IV & OLS & IV & OLS & IV & OLS & IV & OLS & IV \\
\hline \multicolumn{13}{|l|}{ Peer Characteristics } \\
\hline Fraction Female\# & $\begin{array}{l}-.051 * \\
(.012)\end{array}$ & $\begin{array}{l}-.062 * \\
(.014)\end{array}$ & $\begin{array}{l}-.054 * \\
(.012)\end{array}$ & $\begin{array}{l}-.068 * \\
(.014)\end{array}$ & $\begin{array}{l}-.053 * \\
(.014)\end{array}$ & $\begin{array}{l}-.072 * \\
(.018)\end{array}$ & $\begin{array}{l}.006 \\
(.012)\end{array}$ & $\begin{array}{c}.010 \\
(.014)\end{array}$ & $\begin{array}{l}-.001 \\
(.012)\end{array}$ & $\begin{array}{c}.003 \\
(.014)\end{array}$ & $\begin{array}{l}-.004 \\
(.014)\end{array}$ & $\begin{array}{l}-.010 \\
(.017)\end{array}$ \\
\hline Average Age\# & $\begin{array}{l}-.006 \\
(.015)\end{array}$ & $\begin{array}{l}-.018 \\
(.025)\end{array}$ & $\begin{array}{l}-.005 \\
(.015)\end{array}$ & $\begin{array}{l}-.028 \\
(.025)\end{array}$ & $\begin{array}{l}-.021 \\
(.020)\end{array}$ & $\begin{array}{l}-.033 \\
(.029)\end{array}$ & $\begin{array}{l}.034 * \\
(.014)\end{array}$ & $\begin{array}{c}.008 \\
(.024)\end{array}$ & $\begin{array}{l}.028 \\
(.015)\end{array}$ & $\begin{array}{c}.007 \\
(.024)\end{array}$ & $\begin{array}{l}.047 * \\
(.019)\end{array}$ & $\begin{array}{l}.030 \\
(.028)\end{array}$ \\
\hline Mother's Education\# & $\begin{array}{l}.016^{*} \\
(.003)\end{array}$ & $\begin{array}{l}.019 * \\
(.003)\end{array}$ & $\begin{array}{l}.003 \\
(.003)\end{array}$ & $\begin{array}{c}.004 \\
(.003)\end{array}$ & $\begin{array}{l}.002 \\
(.003)\end{array}$ & $\begin{array}{c}.002 \\
(.004)\end{array}$ & $\begin{array}{l}.006 * \\
(.003)\end{array}$ & $\begin{array}{c}.006 \\
(.003)\end{array}$ & $\begin{array}{c}.003 \\
(.003)\end{array}$ & $\begin{array}{c}.002 \\
(.003)\end{array}$ & $\begin{array}{c}.003 \\
(.003)\end{array}$ & $\begin{array}{l}.0001 \\
(.004)\end{array}$ \\
\hline \multicolumn{13}{|c|}{ Individual Characteristics } \\
\hline Mother's Education & $\begin{array}{c}.051 * \\
(.0004)\end{array}$ & $\begin{array}{l}.051 * \\
(.0004)\end{array}$ & $\begin{array}{l}.050 * \\
(.0004)\end{array}$ & $\begin{array}{c}.051 * \\
(.0004)\end{array}$ & $\begin{array}{c}.050 * \\
(.0005)\end{array}$ & $\begin{array}{l}.051 * \\
(.0005)\end{array}$ & $\begin{array}{l}.031 * \\
(.0004)\end{array}$ & $\begin{array}{l}.031 * \\
(.0004)\end{array}$ & $\begin{array}{c}.031 * \\
(.0004)\end{array}$ & $\begin{array}{l}.031 * \\
(.0004)\end{array}$ & $\begin{array}{c}.031 * \\
(.0004)\end{array}$ & $\begin{array}{c}.031 * \\
(.0004)\end{array}$ \\
\hline School Starting Age\# & $\begin{array}{c}-.058 * \\
(.002)\end{array}$ & $\begin{array}{l}.011 * \\
(.003)\end{array}$ & $\begin{array}{c}-.058 * \\
(.002)\end{array}$ & $\begin{array}{l}.011 * \\
(.003)\end{array}$ & $\begin{array}{l}-.059 * \\
(.002)\end{array}$ & $\begin{array}{l}.011 * \\
(.004)\end{array}$ & $\begin{array}{c}-.049 * \\
(.002)\end{array}$ & $\begin{array}{l}.007 * \\
(.003)\end{array}$ & $\begin{array}{c}-.049 * \\
(.002)\end{array}$ & $\begin{array}{l}.007 * \\
(.003)\end{array}$ & $\begin{array}{c}-.049 * \\
(.002)\end{array}$ & $\begin{array}{l}.009 * \\
(.003)\end{array}$ \\
\hline Number of Schools & 1232 & 1232 & 1232 & 1232 & 1231 & 1231 & 1230 & 1230 & 1230 & 1230 & 1228 & 1228 \\
\hline $\mathrm{N}$ & 450,897 & 450,897 & 450,897 & 450,897 & 393,362 & 393,362 & 433,997 & 433,997 & 433,997 & 433,997 & 379,096 & 379,096 \\
\hline
\end{tabular}

All specifications include additional controls for family size, family size squared, an indicator if first born, mother's age at birth, mother's age at birth squared, an indicator for immigrant status, school grade size, and indicators for cohort. IV specifications instrument variables denoted with a \# with what they would be if all students had started school in accordance with the school starting age laws in Norway at that time. Cohort dummies are instrumented with year of birth dummies.

Standard errors are clustered at the school level.

*: Statistically Significant at the 5\% level. 
Table 3: IV Effect of Peers on Various Outcomes

\begin{tabular}{|c|c|c|c|c|c|c|c|c|}
\hline & \multicolumn{4}{|c|}{ Men } & \multicolumn{4}{|c|}{ Women } \\
\hline & Education & IQ Scores & FT & $\begin{array}{c}\text { Log } \\
\text { (Earnings) }\end{array}$ & Education & Teen Birth & FT & $\begin{array}{c}\text { Log } \\
\text { (Earnings) }\end{array}$ \\
\hline \multicolumn{9}{|l|}{ Control for Trends } \\
\hline \multirow[t]{2}{*}{ Fraction Female } & $-.203 *$ & -.068 & -.022 & -.028 & $.143 *$ & $-.023 *$ & $.034^{*}$ & $.077^{*}$ \\
\hline & $(.064)$ & $(.052)$ & $(.013)$ & $(.019)$ & $(.073)$ & $(.011)$ & $(.014)$ & $(.021)$ \\
\hline \multirow[t]{2}{*}{ Mean Age } & $-.226^{*}$ & .006 & .018 & -.016 & -.038 & .020 & -.004 & .049 \\
\hline & $(.112)$ & $(.094)$ & $(.023)$ & $(.035)$ & $(.126)$ & $(.019)$ & $(.025)$ & $(.038)$ \\
\hline \multirow[t]{2}{*}{ Average Mother's Education } & .030 & $.031 *$ & -.002 & -.002 & $.039 *$ & .001 & -.005 & -.003 \\
\hline & $(.016)$ & $(.012)$ & $(.003)$ & $(.005)$ & $(.017)$ & $(.002)$ & $(.003)$ & $(.005)$ \\
\hline $\mathrm{N}$ & 450,561 & 415,123 & 450,897 & 416,746 & 433,769 & 345,682 & 433,997 & 396,239 \\
\hline \multicolumn{9}{|l|}{ Control for Moving Average } \\
\hline \multirow[t]{2}{*}{ Fraction Female } & $-.182 *$ & -.056 & -.032 & -.034 & .029 & $-.026^{*}$ & $.043^{*}$ & $.075 *$ \\
\hline & $(.084)$ & $(.066)$ & $(.017)$ & $(.025)$ & $(.090)$ & $(.013)$ & $(.018)$ & $(.028)$ \\
\hline \multirow[t]{2}{*}{ Mean Age } & -.142 & .015 & .02 & -.008 & .033 & .0006 & -.015 & .036 \\
\hline & $(.137)$ & $(.110)$ & $(.028)$ & $(.042)$ & $(.147)$ & $(.022)$ & $(.029)$ & $(.045)$ \\
\hline \multirow[t]{2}{*}{ Average Mother's Education } & .032 & .027 & -.004 & -.008 & .028 & .003 & -.005 & .002 \\
\hline & $(.020)$ & $(.015)$ & $(.004)$ & $(.006)$ & $(.021)$ & $(.003)$ & $(.004)$ & $(.007)$ \\
\hline $\mathrm{N}$ & 393,079 & 365,545 & 393,362 & 363,618 & 378,906 & 319,162 & 379,096 & 346,191 \\
\hline
\end{tabular}

All specifications include additional controls for whether first-born, school starting age, mother's education, family size, family size squared, mother's age at birth, mother's age at birth squared, an indicator for immigrant status, school grade size, and indicators for cohort. IV specifications instrument all peer variables with what they would be if all students had started school in accordance with the school starting age laws in Norway at that time. Cohort dummies are instrumented with year of birth dummies. School starting age is instrumented with expected school starting age. Standard errors are clustered at the school level.

*: Statistically Significant at the 5\% level. 
Table 4: IV Effect of Peers on Various Outcomes Sibling Fixed Effects

\begin{tabular}{|c|c|c|c|c|c|c|c|c|c|c|}
\hline & \multicolumn{5}{|c|}{ Men } & \multicolumn{5}{|c|}{ Women } \\
\hline & $\begin{array}{c}\text { HS } \\
\text { Track }\end{array}$ & Education & $\begin{array}{c}\text { IQ } \\
\text { Scores }\end{array}$ & FT & $\begin{array}{c}\text { Log } \\
\text { (Earnings) }\end{array}$ & $\begin{array}{c}\text { HS } \\
\text { Track }\end{array}$ & Education & $\begin{array}{l}\text { Teen } \\
\text { Birth }\end{array}$ & FT & $\begin{array}{c}\text { Log } \\
\text { (Earnings) }\end{array}$ \\
\hline Fraction Female & $\begin{array}{l}-.070 * \\
(.021)\end{array}$ & $\begin{array}{l}-.142 \\
(.100)\end{array}$ & $\begin{array}{l}-.130 \\
(.075)\end{array}$ & $\begin{array}{l}-.008 \\
(.022)\end{array}$ & $\begin{array}{l}-.019 \\
(.033)\end{array}$ & $\begin{array}{l}-.037 \\
(.021)\end{array}$ & $\begin{array}{l}.150 \\
(.104)\end{array}$ & $\begin{array}{l}-.029 \\
(.018)\end{array}$ & $\begin{array}{c}.030 \\
(.025)\end{array}$ & $\begin{array}{l}.048 \\
(.039)\end{array}$ \\
\hline Mean Age & $\begin{array}{l}-.054 \\
(.038)\end{array}$ & $\begin{array}{l}-.248 \\
(.184)\end{array}$ & $\begin{array}{l}.165 \\
(.139)\end{array}$ & $\begin{array}{c}.014 \\
(.041)\end{array}$ & $\begin{array}{l}-.013 \\
(.060)\end{array}$ & $\begin{array}{l}-.053 \\
(.039)\end{array}$ & $\begin{array}{l}-.040 \\
(.191)\end{array}$ & $\begin{array}{l}-.029 \\
(.033)\end{array}$ & $\begin{array}{l}-.008 \\
(.047)\end{array}$ & $\begin{array}{c}.031 \\
(.071)\end{array}$ \\
\hline $\begin{array}{l}\text { Average Mother's } \\
\text { Education }\end{array}$ & $\begin{array}{l}-.004 \\
(.005)\end{array}$ & $\begin{array}{l}.005 \\
(.023)\end{array}$ & $\begin{array}{l}-.030 \\
(.017)\end{array}$ & $\begin{array}{l}.007 \\
(.005)\end{array}$ & $\begin{array}{l}.002 \\
(.008)\end{array}$ & $\begin{array}{l}-.002 \\
(.005)\end{array}$ & $\begin{array}{l}.024 \\
(.024)\end{array}$ & $\begin{array}{l}-.009 \\
(.004)\end{array}$ & $\begin{array}{l}-.009 \\
(.006)\end{array}$ & $\begin{array}{c}.007 \\
(.009)\end{array}$ \\
\hline $\begin{array}{l}\text { Families } \\
\mathrm{N}\end{array}$ & $\begin{array}{c}82,133 \\
180,964\end{array}$ & $\begin{array}{c}82,129 \\
180,828\end{array}$ & $\begin{array}{c}81,050 \\
166,907\end{array}$ & $\begin{array}{c}82,133 \\
180,964\end{array}$ & $\begin{array}{c}81,499 \\
168,639\end{array}$ & $\begin{array}{c}76,718 \\
168,940\end{array}$ & $\begin{array}{c}76,718 \\
168,868\end{array}$ & $\begin{array}{c}73,984 \\
141,686\end{array}$ & $\begin{array}{c}76,718 \\
168,940\end{array}$ & $\begin{array}{c}75,959 \\
155,523\end{array}$ \\
\hline
\end{tabular}

All specifications include additional controls for gender, whether first-born, school starting age, mother's education, mother's age at birth, mother's age at birth squared, an indicator for immigrant status, school grade size, and indicators for cohort. IV specifications instrument all peer variables with what they would be if all students had started school in accordance with the school starting age laws in Norway at that time. Cohort dummies are instrumented with year of birth dummies. School starting age is instrumented with expected school starting age. Standard errors are clustered at the school level.

*: Statistically Significant at the 5\% level. 
Table 5: IV Effect of Peers on Various Outcomes

Recent Cohorts

\begin{tabular}{|c|c|c|c|c|c|c|c|c|c|}
\hline & \multicolumn{3}{|c|}{ All } & \multicolumn{3}{|c|}{$\overline{M e n}$} & \multicolumn{3}{|c|}{ Women } \\
\hline Control for Trends & HS Track & $\begin{array}{l}\text { Math } \\
\text { Score1 }\end{array}$ & $\begin{array}{c}\text { Math } \\
\text { Score2 }\end{array}$ & HS Track & $\begin{array}{l}\text { Math } \\
\text { Score } 1\end{array}$ & $\begin{array}{c}\text { Math } \\
\text { Score 2 }\end{array}$ & $\begin{array}{c}\text { HS } \\
\text { Track }\end{array}$ & $\begin{array}{l}\text { Math } \\
\text { Score1 }\end{array}$ & $\begin{array}{c}\text { Math } \\
\text { Score2 }\end{array}$ \\
\hline Fraction Female & $\begin{array}{l}-.033^{*} \\
(.008)\end{array}$ & $\begin{array}{l}.019 \\
(.042)\end{array}$ & $\begin{array}{l}.136 \\
(.081)\end{array}$ & $\begin{array}{l}-.045^{*} \\
.012)\end{array}$ & $\begin{array}{l}.007 \\
(.055)\end{array}$ & $\begin{array}{l}.098 \\
(.101)\end{array}$ & $\begin{array}{l}-.014 \\
(.012)\end{array}$ & $\begin{array}{l}.035 \\
(.056)\end{array}$ & $\begin{array}{l}.182 \\
(.099)\end{array}$ \\
\hline Average Age & $\begin{array}{l}-.008 \\
(.015)\end{array}$ & $\begin{array}{l}-.099 \\
(.079)\end{array}$ & $\begin{array}{l}.111 \\
(.132)\end{array}$ & $\begin{array}{l}-.026 \\
(.022)\end{array}$ & $\begin{array}{l}-.144 \\
(.101)\end{array}$ & $\begin{array}{l}.017 \\
(.174)\end{array}$ & $\begin{array}{l}.011 \\
(.021)\end{array}$ & $\begin{array}{l}-.047 \\
(.103)\end{array}$ & $\begin{array}{c}.216 \\
(.158)\end{array}$ \\
\hline $\begin{array}{l}\text { Average Mother's } \\
\text { Education }\end{array}$ & $\begin{array}{l}.003 \\
(.002)\end{array}$ & $\begin{array}{l}.015 \\
(.009)\end{array}$ & $\begin{array}{l}.037^{*} \\
(.015)\end{array}$ & $\begin{array}{l}.001 \\
(.003)\end{array}$ & $\begin{array}{l}.006 \\
(.012)\end{array}$ & $\begin{array}{l}.042 * \\
(.019)\end{array}$ & $\begin{array}{l}.005 \\
(.002)\end{array}$ & $\begin{array}{l}.024 \\
(.012)\end{array}$ & $\begin{array}{l}.034 \\
(.020)\end{array}$ \\
\hline $\begin{array}{l}\text { Number of Schools } \\
\mathrm{N} \\
\text { Control for Moving }\end{array}$ & $\begin{array}{l}1262 \\
788340 \\
\text { erage }\end{array}$ & $\begin{array}{c}1112 \\
251786\end{array}$ & $\begin{array}{c}1062 \\
96261\end{array}$ & $\begin{array}{c}1261 \\
403595\end{array}$ & $\begin{array}{c}1102 \\
128632\end{array}$ & $\begin{array}{c}1042 \\
49374\end{array}$ & $\begin{array}{c}1259 \\
384745\end{array}$ & $\begin{array}{c}1105 \\
123154\end{array}$ & $\begin{array}{c}1048 \\
46887\end{array}$ \\
\hline Fraction Female & $\begin{array}{l}-.044^{*} \\
(.010)\end{array}$ & $\begin{array}{l}.121^{*} \\
(.055)\end{array}$ & $\begin{array}{l}.210^{*} \\
(.108)\end{array}$ & $\begin{array}{l}-.040^{*} \\
(.015)\end{array}$ & $\begin{array}{l}.153^{*} \\
(.072)\end{array}$ & $\begin{array}{l}.159 \\
(.134)\end{array}$ & $\begin{array}{l}-.026 \\
(.015)\end{array}$ & $\begin{array}{c}.098 \\
(.071)\end{array}$ & $\begin{array}{l}.270^{*} \\
(.132)\end{array}$ \\
\hline Average Age & $\begin{array}{l}-.017 \\
(.018)\end{array}$ & $\begin{array}{l}-.028 \\
(.097)\end{array}$ & $\begin{array}{l}.147 \\
(.175)\end{array}$ & $\begin{array}{l}-.062^{*} \\
(.026)\end{array}$ & $\begin{array}{l}.001 \\
(.126)\end{array}$ & $\begin{array}{l}.162 \\
(.224)\end{array}$ & $\begin{array}{l}.031 \\
(.026)\end{array}$ & $\begin{array}{l}-.042 \\
(.125)\end{array}$ & $\begin{array}{l}.151 \\
(.208)\end{array}$ \\
\hline $\begin{array}{l}\text { Average Mother's } \\
\text { Education }\end{array}$ & $\begin{array}{l}.001 \\
(.002)\end{array}$ & $\begin{array}{l}.015 \\
(.011)\end{array}$ & $\begin{array}{l}.017 \\
(.020)\end{array}$ & $\begin{array}{l}-.001 \\
(.003)\end{array}$ & $\begin{array}{l}-.006 \\
(.014)\end{array}$ & $\begin{array}{l}-.001 \\
(.024)\end{array}$ & $\begin{array}{l}.003 \\
(.003)\end{array}$ & $\begin{array}{l}.037^{*} \\
(.015)\end{array}$ & $\begin{array}{l}.032 \\
(.026)\end{array}$ \\
\hline $\begin{array}{l}\text { Number of Schools } \\
N\end{array}$ & $\begin{array}{c}1262 \\
685132\end{array}$ & $\begin{array}{c}1109 \\
199278\end{array}$ & $\begin{array}{c}1028 \\
76892\end{array}$ & $\begin{array}{c}1261 \\
350783\end{array}$ & $\begin{array}{c}1099 \\
101773\end{array}$ & $\begin{array}{c}1004 \\
39444\end{array}$ & $\begin{array}{c}1257 \\
334349\end{array}$ & $\begin{array}{c}1101 \\
97505\end{array}$ & $\begin{array}{c}1010 \\
37448\end{array}$ \\
\hline
\end{tabular}

All specifications include additional controls for whether first-born, school starting age, mother's education, family size, family size squared, mother's age at birth, mother's age at birth squared, an indicator for immigrant status, school grade size, and indicators for cohort. IV specifications instrument all peer variables with what they would be if all students had started school in accordance with the school starting age laws in Norway at that time. Cohort dummies are instrumented with year of birth dummies. School starting age is instrumented with expected school starting age. Standard errors are clustered at the school level.

*: Statistically Significant at the 5\% level. 


\section{Table 6: IV Estimates of Effect of Peer Characteristics on Educational Track and Test Scores Sibling Fixed Effects/Recent Cohorts}

Fraction Female

Average Age

Mother's Education

Number of Families

$\mathrm{N}$
$-.031^{*}$

$(.011)$

.010

$(.019)$

$-.002$

$(.002)$

204,632

464,083
.098

$-.287 *$

$(.100)$

$-.019$

100,620

137,567

All specifications include additional controls for gender, school starting age, mother's education, mother's age at birth, mother's age at birth squared, an indicator for immigrant status, school grade size, and indicators for cohort. IV specifications instrument all variables with what they would be if all students had started school in accordance with the school starting age laws in Norway at that time. Cohort dummies are instrumented with year of birth dummies.

Standard errors are clustered at the school level.

*: Statistically Significant at the 5\% level. 
Table 7: IV Effect of Peers on Various Outcomes--Non-Linear Effects

\begin{tabular}{|c|c|c|c|c|c|c|c|c|c|c|}
\hline & HS Track & Education & $\begin{array}{c}\text { Men } \\
\text { IQ Scores }\end{array}$ & FT & $\begin{array}{c}\log \\
\text { (Earnings) }\end{array}$ & HS Track & Education & $\begin{array}{l}\text { Women } \\
\text { Teen } \\
\text { Birth }\end{array}$ & FT & $\begin{array}{c}\log \\
\text { (Earnings) }\end{array}$ \\
\hline \multicolumn{11}{|l|}{ Control for Trends } \\
\hline Fraction Female & $\begin{array}{l}-.068^{*} \\
(.014)\end{array}$ & $\begin{array}{l}-.200 * \\
(.064)\end{array}$ & $\begin{array}{l}-.073 \\
(.053)\end{array}$ & $\begin{array}{l}-.022 \\
(.013)\end{array}$ & $\begin{array}{l}-.029 \\
(.019)\end{array}$ & $\begin{array}{l}.004 \\
(.014)\end{array}$ & $\begin{array}{l}.146^{*} \\
(.073)\end{array}$ & $\begin{array}{l}-.023 * \\
(.011)\end{array}$ & $\begin{array}{l}.033^{*} \\
(.014)\end{array}$ & $\begin{array}{l}.077^{*} \\
(.021)\end{array}$ \\
\hline Mean Age & $\begin{array}{l}-.031 \\
(.025)\end{array}$ & $\begin{array}{l}-.233^{*} \\
(.115)\end{array}$ & $\begin{array}{c}.043 \\
(.095)\end{array}$ & $\begin{array}{l}.023 \\
(.024)\end{array}$ & $\begin{array}{l}-.019 \\
(.036)\end{array}$ & $\begin{array}{l}.007 \\
(.025)\end{array}$ & $\begin{array}{l}-.049 \\
(.130)\end{array}$ & $\begin{array}{c}.019 \\
(.020)\end{array}$ & $\begin{array}{l}.0005 \\
(.026)\end{array}$ & $\begin{array}{c}.049 \\
(.039)\end{array}$ \\
\hline $\begin{array}{l}\text { Average Mother's } \\
\text { Education }\end{array}$ & $\begin{array}{l}.008 * \\
(.004)\end{array}$ & $\begin{array}{l}.050 * \\
(.018)\end{array}$ & $\begin{array}{l}.051^{*} \\
(.014)\end{array}$ & $\begin{array}{l}.002 \\
(.004)\end{array}$ & $\begin{array}{l}.005 \\
(.006)\end{array}$ & $\begin{array}{l}.008 * \\
(.004)\end{array}$ & $\begin{array}{l}.059 * \\
(.020)\end{array}$ & $\begin{array}{l}-.002 \\
(.003)\end{array}$ & $\begin{array}{l}-.004 \\
(.004)\end{array}$ & $\begin{array}{l}.001 \\
(.006)\end{array}$ \\
\hline $\begin{array}{l}\text { Standard Deviation of } \\
\text { Mother's Education }\end{array}$ & $\begin{array}{l}-.010^{*} \\
(.005)\end{array}$ & $\begin{array}{l}-.046^{*} \\
(.022)\end{array}$ & $\begin{array}{l}-.042 * \\
(.018)\end{array}$ & $\begin{array}{l}-.008 \\
(.004)\end{array}$ & $\begin{array}{r}-.017 * \\
(.006)\end{array}$ & $\begin{array}{l}-.014^{*} \\
(.005)\end{array}$ & $\begin{array}{r}-.046^{*} \\
(.024)\end{array}$ & $\begin{array}{l}.006 \\
(.003)\end{array}$ & $\begin{array}{l}-.001 \\
(.005)\end{array}$ & $\begin{array}{l}-.009 \\
(.007)\end{array}$ \\
\hline $\begin{array}{l}\text { Standard Deviation of } \\
\text { Age }\end{array}$ & $\begin{array}{l}-.009 \\
(.062)\end{array}$ & $\begin{array}{l}-.073 \\
(.292)\end{array}$ & $\begin{array}{l}.366 \\
(.241)\end{array}$ & $\begin{array}{l}.042 \\
(.060)\end{array}$ & $\begin{array}{l}-.013 \\
(.091)\end{array}$ & $\begin{array}{l}.005 \\
(.062)\end{array}$ & $\begin{array}{l}-.109 \\
(.319)\end{array}$ & $\begin{array}{l}.004 \\
(.047)\end{array}$ & $\begin{array}{l}.042 \\
(.062)\end{array}$ & $\begin{array}{l}-.001 \\
(.095)\end{array}$ \\
\hline \multicolumn{11}{|c|}{ Control for Moving Average } \\
\hline Fraction Female & $\begin{array}{l}-.072 * \\
(.018)\end{array}$ & $\begin{array}{l}-.182^{*} \\
(.084)\end{array}$ & $\begin{array}{l}-. .063 \\
(.067)\end{array}$ & $\begin{array}{l}-.033^{*} \\
(.017)\end{array}$ & $\begin{array}{l}-. .036 \\
(.025)\end{array}$ & $\begin{array}{l}-.010 \\
(.017)\end{array}$ & $\begin{array}{l}.021 \\
(.093)\end{array}$ & $\begin{array}{l}-.025 \\
(.013)\end{array}$ & $\begin{array}{l}.038^{*} \\
(.018)\end{array}$ & $\begin{array}{l}.075^{*} \\
(.029)\end{array}$ \\
\hline Mean Age & $\begin{array}{l}-.030 \\
(.030)\end{array}$ & $\begin{array}{l}-.146 \\
(.141)\end{array}$ & $\begin{array}{l}.051 \\
(.113)\end{array}$ & $\begin{array}{l}.036 \\
(.028)\end{array}$ & $\begin{array}{l}-.003 \\
(.043)\end{array}$ & $\begin{array}{l}.030 \\
(.029)\end{array}$ & $\begin{array}{l}.061 \\
(.155)\end{array}$ & $\begin{array}{l}-.005 \\
(.024)\end{array}$ & $\begin{array}{l}-.002 \\
(.031)\end{array}$ & $\begin{array}{l}.037 \\
(.047)\end{array}$ \\
\hline $\begin{array}{l}\text { Average Mother's } \\
\text { Education }\end{array}$ & $\begin{array}{l}.005 \\
(.005)\end{array}$ & $\begin{array}{l}.053^{*} \\
(.023)\end{array}$ & $\begin{array}{l}.045^{*} \\
(.018)\end{array}$ & $\begin{array}{l}-.001 \\
(.005)\end{array}$ & $\begin{array}{l}-.004 \\
(.007)\end{array}$ & $\begin{array}{l}.008 \\
(.005)\end{array}$ & $\begin{array}{l}.057^{*} \\
(.025)\end{array}$ & $\begin{array}{l}.001 \\
(.003)\end{array}$ & $\begin{array}{l}-.003 \\
(.005)\end{array}$ & $\begin{array}{l}.011 \\
(.007)\end{array}$ \\
\hline $\begin{array}{l}\text { Standard Deviation of } \\
\text { Mother's Education }\end{array}$ & $\begin{array}{l}-.006 \\
(.006)\end{array}$ & $\begin{array}{l}-.048^{*} \\
(.028)\end{array}$ & $\begin{array}{l}-.036 \\
(.022)\end{array}$ & $\begin{array}{l}-.008 \\
(.006)\end{array}$ & $\begin{array}{l}-.009 \\
(.008)\end{array}$ & $\begin{array}{l}-.018^{*} \\
(.006)\end{array}$ & $\begin{array}{l}-.064 * \\
(.030)\end{array}$ & $\begin{array}{l}.003 \\
(.004)\end{array}$ & $\begin{array}{l}-.004 \\
(.006)\end{array}$ & $\begin{array}{l}-.021^{*} \\
(.009)\end{array}$ \\
\hline $\begin{array}{l}\text { Standard Deviation of } \\
\text { Age }\end{array}$ & $\begin{array}{l}.040 \\
(.080)\end{array}$ & $\begin{array}{l}-.012 \\
(.382)\end{array}$ & $\begin{array}{l}.370 \\
(.304)\end{array}$ & $\begin{array}{l}.078 \\
(.075)\end{array}$ & $\begin{array}{l}.036 \\
(.025)\end{array}$ & $\begin{array}{l}.018 \\
(.079)\end{array}$ & $\begin{array}{l}.227 \\
(.433)\end{array}$ & $\begin{array}{l}-.052 \\
(.059)\end{array}$ & $\begin{array}{l}.113 \\
(.082)\end{array}$ & $\begin{array}{l}.022 \\
(.125)\end{array}$ \\
\hline
\end{tabular}


All specifications include additional controls for whether first-born, school starting age, mother's education, family size, family size squared, mother's age at birth, mother's age at birth squared, an indicator for immigrant status, school grade size, and indicators for cohort. IV specifications instrument all peer variables with what they would be if all students had started school in accordance with the school starting age laws in Norway at that time. Cohort dummies are instrumented with year of birth dummies. School starting age is instrumented with expected school starting age. Standard errors are clustered at the school level.

*: Statistically Significant at the 5\% level. 
Appendix Table 1: Effect of Peers on Predetermined Characteristics (IV Estimates)

Controls for School Means

\begin{tabular}{|c|c|c|c|c|c|c|c|c|}
\hline & $\begin{array}{l}\text { Mother's } \\
\text { Education }\end{array}$ & $\begin{array}{c}\text { Father's } \\
\text { Education }\end{array}$ & $\begin{array}{c}\text { Family } \\
\text { Size }\end{array}$ & $\begin{array}{c}\text { Whether } \\
\text { First-born }\end{array}$ & $\begin{array}{c}\text { Expected } \\
\text { School } \\
\text { Starting } \\
\text { Age }\end{array}$ & $\begin{array}{c}\text { Mother's } \\
\text { Age at } \\
\text { Birth }\end{array}$ & $\begin{array}{c}\text { Whether } \\
\text { Immigrant }\end{array}$ & $\begin{array}{l}\text { Whether } \\
\text { Female }\end{array}$ \\
\hline Average Age & $\begin{array}{l}.185^{*} \\
(.070)\end{array}$ & $\begin{array}{l}.272 * \\
(.093)\end{array}$ & $\begin{array}{c}-.096 * \\
(.049)\end{array}$ & $\begin{array}{c}.011 \\
(.018)\end{array}$ & $\begin{array}{l}-.078^{*} \\
(.014)\end{array}$ & $\begin{array}{l}-.067 \\
(.233)\end{array}$ & $\begin{array}{c}.007 \\
(.004)\end{array}$ & $\begin{array}{l}-.004 \\
(.018)\end{array}$ \\
\hline $\begin{array}{l}\text { Mother's } \\
\text { Education }\end{array}$ & $\begin{array}{l}.189 * \\
(.017)\end{array}$ & $\begin{array}{l}.363^{*} \\
(.024)\end{array}$ & $\begin{array}{l}-.120^{*} \\
(.018)\end{array}$ & $\begin{array}{l}.005 \\
(.003)\end{array}$ & $\begin{array}{l}.001 \\
(.001)\end{array}$ & $\begin{array}{l}.217^{*} \\
(.045)\end{array}$ & $\begin{array}{l}.001 \\
(.001)\end{array}$ & $\begin{array}{l}.001 \\
(.002)\end{array}$ \\
\hline
\end{tabular}

\section{Controls for School Means and Trends}

\begin{tabular}{l|ccccccccc}
\hline & $\begin{array}{c}\text { Mother's } \\
\text { Education }\end{array}$ & $\begin{array}{c}\text { Father's } \\
\text { Education }\end{array}$ & $\begin{array}{c}\text { Family } \\
\text { Size }\end{array}$ & $\begin{array}{c}\text { Whether } \\
\text { First-born }\end{array}$ & $\begin{array}{c}\text { Expected } \\
\text { School } \\
\text { Starting } \\
\text { Age }\end{array}$ & $\begin{array}{c}\text { Mother's } \\
\text { Age at } \\
\text { Birth }\end{array}$ & $\begin{array}{c}\text { Whether } \\
\text { Immigrant }\end{array}$ & $\begin{array}{c}\text { Whether } \\
\text { Female }\end{array}$ \\
\hline $\begin{array}{l}\text { Fraction } \\
\text { Female }\end{array}$ & -.017 & .022 & -.003 & -.002 & -.002 & .118 & -.003 & $-.179^{*}$ \\
& $(.051)$ & $(.053)$ & $(.025)$ & $(.009)$ & $(.006)$ & $(.120)$ & $(.002)$ & $(.016)$ \\
Average Age & .051 & .149 & -.054 & $.035^{*}$ & -.190 & -.725 & .005 & .013 \\
Mother's & $(.097)$ & $(.101)$ & $(.045)$ & $(.018)$ & $(.016)$ & $(.219)$ & $(.004)$ & $(.021)$ \\
Education & $-.289^{*}$ & $-.120^{*}$ & $.015^{*}$ & -.004 & .002 & .092 & $-.0015^{*}$ & -.001 \\
\hline
\end{tabular}


Controls for School Means and Moving Average

\begin{tabular}{|c|c|c|c|c|c|c|c|c|}
\hline & $\begin{array}{l}\text { Mother's } \\
\text { Education }\end{array}$ & $\begin{array}{c}\text { Father's } \\
\text { Education }\end{array}$ & $\begin{array}{c}\text { Family } \\
\text { Size }\end{array}$ & $\begin{array}{c}\text { Whether } \\
\text { First-born }\end{array}$ & $\begin{array}{c}\text { Expected } \\
\text { School } \\
\text { Starting } \\
\text { Age }\end{array}$ & $\begin{array}{c}\text { Mother's } \\
\text { Age at } \\
\text { Birth }\end{array}$ & $\begin{array}{c}\text { Whether } \\
\text { Immigrant }\end{array}$ & $\begin{array}{l}\text { Whether } \\
\text { Female }\end{array}$ \\
\hline $\begin{array}{l}\text { Fraction } \\
\text { Female }\end{array}$ & $\begin{array}{l}-.012 \\
(.093)\end{array}$ & $\begin{array}{c}.039 \\
(.077)\end{array}$ & $\begin{array}{l}-.019 \\
(.036)\end{array}$ & $\begin{array}{c}.003 \\
(.012)\end{array}$ & $\begin{array}{c}.001 \\
(.012)\end{array}$ & $\begin{array}{l}.150 \\
(.157)\end{array}$ & $\begin{array}{l}-.002 \\
(.003)\end{array}$ & $\begin{array}{l}-.601 * \\
(.028)\end{array}$ \\
\hline Average Age & $\begin{array}{l}-.074 \\
(.153)\end{array}$ & $\begin{array}{c}.090 \\
(.132)\end{array}$ & $\begin{array}{l}-.013 \\
(.060)\end{array}$ & $\begin{array}{l}.070 * \\
(.021)\end{array}$ & $\begin{array}{l}-.547^{*} \\
(.028)\end{array}$ & $\begin{array}{c}-1.153 * \\
(.272)\end{array}$ & $\begin{array}{c}.009 \\
(.005)\end{array}$ & $\begin{array}{l}-.038 \\
(.034)\end{array}$ \\
\hline $\begin{array}{l}\text { Mother's } \\
\text { Education }\end{array}$ & $\begin{array}{l}-.702 * \\
(.032) \\
\end{array}$ & $\begin{array}{l}-.323^{*} \\
(.024) \\
\end{array}$ & $\begin{array}{l}.042 * \\
(.009) \\
\end{array}$ & $\begin{array}{l}-.020^{*} \\
(.003) \\
\end{array}$ & $\begin{array}{c}.001 \\
(.003) \\
\end{array}$ & $\begin{array}{l}.266^{*} \\
(.038) \\
\end{array}$ & $\begin{array}{r}-.003^{*} \\
(.001) \\
\end{array}$ & $\begin{array}{l}-.001 \\
(.005) \\
\end{array}$ \\
\hline \multicolumn{9}{|c|}{ Controls for School Means and Adjusted Moving Average } \\
\hline & $\begin{array}{l}\text { Mother's } \\
\text { Education }\end{array}$ & $\begin{array}{c}\text { Father's } \\
\text { Education }\end{array}$ & $\begin{array}{c}\text { Family } \\
\text { Size }\end{array}$ & $\begin{array}{c}\text { Whether } \\
\text { First-born }\end{array}$ & $\begin{array}{c}\text { Expected } \\
\text { School } \\
\text { Starting } \\
\text { Age }\end{array}$ & $\begin{array}{c}\text { Mother's } \\
\text { Age at } \\
\text { Birth }\end{array}$ & $\begin{array}{l}\text { Whether } \\
\text { Immigrant }\end{array}$ & $\begin{array}{l}\text { Whether } \\
\text { Female }\end{array}$ \\
\hline $\begin{array}{l}\text { Fraction } \\
\text { Female }\end{array}$ & $\begin{array}{c}.006 \\
(.061)\end{array}$ & $\begin{array}{c}.037 \\
(.070)\end{array}$ & $\begin{array}{l}-.011 \\
(.036)\end{array}$ & $\begin{array}{c}.002 \\
(.012)\end{array}$ & $\begin{array}{l}-.003 \\
(.007)\end{array}$ & $\begin{array}{c}.129 \\
(.155)\end{array}$ & $\begin{array}{l}-.002 \\
(.003)\end{array}$ & $\begin{array}{c}.007 \\
(.018)\end{array}$ \\
\hline Average Age & $\begin{array}{l}.071 \\
(.102)\end{array}$ & $\begin{array}{l}.131 \\
(.119)\end{array}$ & $\begin{array}{l}-.014 \\
(.060)\end{array}$ & $\begin{array}{l}.069^{*} \\
(.021)\end{array}$ & $\begin{array}{l}-.003 \\
(.017)\end{array}$ & $\begin{array}{l}-.516 \\
(.269)\end{array}$ & $\begin{array}{l}.010 \\
(.005)\end{array}$ & $\begin{array}{l}-.018 \\
(.021)\end{array}$ \\
\hline $\begin{array}{l}\text { Mother's } \\
\text { Education }\end{array}$ & $\begin{array}{l}-.077 * \\
(.021)\end{array}$ & $\begin{array}{l}-.019 \\
(.020)\end{array}$ & $\begin{array}{l}-.006 \\
(.009)\end{array}$ & $\begin{array}{l}-.0002 \\
(.003)\end{array}$ & $\begin{array}{c}.001 \\
(.002)\end{array}$ & $\begin{array}{c}.065 \\
(.037)\end{array}$ & $\begin{array}{r}-.0003 \\
(.001)\end{array}$ & $\begin{array}{l}-.001 \\
(.003)\end{array}$ \\
\hline
\end{tabular}

Each column reports the estimates from a separate regression. All specifications include additional controls for indicators for cohort. IV specifications instrument all peer variables with what they would be if all students had started school in accordance with the school starting age laws in Norway at that time. Cohort dummies are instrumented with year of birth dummies. Standard errors are clustered at the school level.

*: Statistically Significant at the 5\% level. 


\begin{tabular}{|c|c|c|}
\hline Individual Characteristics & Girls & Boys \\
\hline Mother's Education & $\begin{array}{l}11.58 \\
(2.63)\end{array}$ & $\begin{array}{l}11.61 \\
(2.63)\end{array}$ \\
\hline Mother's Age at Birth & $\begin{array}{l}27.00 \\
(5.04)\end{array}$ & $\begin{array}{l}27.00 \\
(5.04)\end{array}$ \\
\hline Family Size & $\begin{array}{c}2.72 \\
(1.08)\end{array}$ & $\begin{array}{c}2.73 \\
(1.08)\end{array}$ \\
\hline Fraction Firstborn & $\begin{array}{c}.44 \\
(.50)\end{array}$ & $\begin{array}{c}.44 \\
(.50)\end{array}$ \\
\hline Immigrant & $\begin{array}{c}.04 \\
(.19)\end{array}$ & $\begin{array}{c}.03 \\
(.18)\end{array}$ \\
\hline Fraction Students Starting On Time & $\begin{array}{l}.975 \\
(.156)\end{array}$ & $\begin{array}{l}.975 \\
(.155)\end{array}$ \\
\hline School Starting Age & $\begin{array}{l}7.25 \\
(.28)\end{array}$ & $\begin{array}{l}7.26 \\
(.30)\end{array}$ \\
\hline Expected School Starting Age & $\begin{array}{l}7.25 \\
(.28)\end{array}$ & $\begin{array}{l}7.25 \\
(.28)\end{array}$ \\
\hline Fraction doing Academic Track in High School & $\begin{array}{l}.70 \\
(.45)\end{array}$ & $\begin{array}{l}.46 \\
(.50)\end{array}$ \\
\hline Fraction doing Vocational Track & $\begin{array}{l}.29 \\
(.45)\end{array}$ & $\begin{array}{l}.52 \\
(.50)\end{array}$ \\
\hline Math Score 1 & $\begin{array}{l}3.53 \\
(1.12)\end{array}$ & $\begin{array}{l}3.40 \\
(1.15)\end{array}$ \\
\hline Math Score 2 & $\begin{array}{c}3.24 \\
(1.10)\end{array}$ & $\begin{array}{c}3.19 \\
(1.13)\end{array}$ \\
\hline \multicolumn{3}{|l|}{ School/Peer Characteristics } \\
\hline \# of Students in Grade & $\begin{array}{c}80 \\
(40)\end{array}$ & $\begin{array}{c}79 \\
(40)\end{array}$ \\
\hline Average Age & $\begin{array}{l}7.3 \\
(.07)\end{array}$ & $\begin{array}{l}7.3 \\
(.07)\end{array}$ \\
\hline Average Female & $\begin{array}{c}.49 \\
(.08)\end{array}$ & $\begin{array}{c}.49 \\
(.08)\end{array}$ \\
\hline Average Mother's Education & $\begin{array}{l}11.60 \\
(.82)\end{array}$ & $\begin{array}{l}11.60 \\
(.82)\end{array}$ \\
\hline $\begin{array}{l}\mathrm{N}^{*} \\
\text { Number of Schools }\end{array}$ & $\begin{array}{c}384,745 \\
1,259\end{array}$ & $\begin{array}{c}403,599 \\
1,261\end{array}$ \\
\hline
\end{tabular}

* For girls, there are 123,154 observations on Math Score 1 and 46,887 observations on Math Score 2. For boys, there are 128,632 observations on Math Score 1 and 49,374 observations on Math Score. Standard deviations in parentheses. 